\title{
Vulnerability and Coping Strategies of Women in Disaster: A Study on Coastal Areas of Bangladesh
}

\author{
Md. Rabiul Islam*
}

\section{Introduction}

Natural disaster is a common phenomenon in Bangladesh. Almost every year Bangladesh suffers highly by different kinds of disasters like flood, tropical cyclones, tornados, tidal surges, droughts and large scale river erosion etc. Bangladesh is a low lying delta with very gentle slopes. It is located at the lowest end of the Ganges, Brahmaputra and Meghna Basin (Roy et al 2009). Bangladesh has special geographical feature. It has the Himalayan range to the north, the Bay of Bengal to the south with its funneling towards Meghna estuary and the vast stretch of Indian land to the west. These special geographical features have significant impact on the weather system of Bangladesh. Due to this weather system, Bangladesh is the worst victimized country of natural disasters which causes loss of lives and properties (Nizamuddin 2001). A large number of the total population of our country lives in the coastal areas. According to the population census 2001, the whole coastal area of the country has about 46 million people. The average size of the household is 7 , the density of population is 743 per sq. $\mathrm{km}$. Womenfolk are $49 \%$ of the coastal population, while $23 \%$ (8 million) are urban-dwellers, size of the labor force (15-59 years age group) is 18.6 million which are about $53 \%$ of the coastal population (BBS 2006).

Due to climate change, most of the coastal areas of the world are at risk from natural disasters and meteorological disturbances. The coastal areas of Bangladesh are not in different

\footnotetext{
*Assistant Professor, Institute of Social Welfare and Research, University of
} Dhaka. 
situation from it. These areas are ecologically sensitive and climatically vulnerable because a process of erosion and accretion is continued. The coastal areas of Bangladesh are facing the Bay of Bengal with an area of 472,201 sq. $\mathrm{km}$ where 19 districts are included (and that is the reason which has made the country one of the most disaster prone country (CPD; 2000). As the Bay of Bengal is a perfect breading ground for tropical cyclones, the coastal areas have been facing one or two severe disaster every year. For example, cyclones, SIDR and AILA can be mentioned. Disaster in Bangladesh is considered to be a great constraint for sustainable development. Cyclone, tidal surge, flood, river bank erosion are some of the worst types of disaster which is badly affecting the livelihood of our citizens especially in the coastal zone (Alam 2005). Women are supposed to be the most vulnerable for many causes namely their vulnerability, mental attitude, physical structure and other social issues (Mitchell 2007). There exists a lot of problems and lacking in disaster management. Though the vulnerable women of the coastal areas are not getting proper support from the government and non-government authorities, their indigenous coping capacities are appreciable. Due to disasters, sometimes women have to migrate from their residence to different metropolitan cities. It increases different urban problems like unemployment, criminal activities, traffic jam, slum problem etc. (DMB 2009). The present study is conducted to know the vulnerability of women and their coping strategies during disasters so that it can be helpful for further research on this issue.

We live in a society where women and children are the most vulnerable group. During disaster, this vulnerability increases. Though disasters do not discriminate, the socially constructed role of women makes them the vulnerable group during disaster. Because women have less access to resources, they are victims of the gendered division of labor, they are primarily responsible for domestic duties and they do not have the liberty of migrating to look for work following a disaster (World Bank 2005). The differentiated impact of disasters on men and women is primarily caused by the existing gender inequalities manifested. A study conducted by London School of Economics shows, taken a sample of up to 141 countries over the period 1981 to 2002, natural disasters and their subsequent impact, on average kill more women 
than men or kill women at earlier age than men related to women's lower socio-economic status (Newmayer and Plumper 2007). Another thing is recognized worldwide that people's vulnerability to risks depend to a large extent on the assets they have available. In Bangladesh, women tend to have more limited access to assetsphysical, financial, human, social and natural capital such as land, credit, decision making bodies, agricultural inputs, technology, extension and training services which would all enhance their capacity to adopt. And in the coastal areas of Bangladesh, the situation is worst (Soussan and Anjan 2002). The total population affected in different coastal areas (Koira, Dacope and Shyamnagar Upazila) by cyclone AILA was 290327. Among them women of 18 to 60 years age group were 87377 , whereas men were 80406 . Boys of 5-18 years age group were 43766, but the number of affected girls of this age group was 47219 (Action Aid 2009).

Women are a more vulnerable group in disastrous situation and they need to be taken care of. Initiatives should be taken for this vulnerable group so that they can cope with disaster more effectively. Now-a-days not only the natural disasters but also many man-made disasters are occurring in our country such as water logging, road accidents, catastrophic fire etc. As women are half of the total population of our country, their risks in disastrous situation is not avoidable. A developing country like ours where women are not considered as equally important as men, have many problems to manage their risks in all these disasters. Women in Bangladesh still experience various types of violence physical, sexual, emotional and domestic (abusive language or exertion of physical force) that increases during and after a disaster (Ali 1999). The present study is conducted to realize the vulnerability of women during disaster and their coping strategies to combat disaster.

Over the last decade, the disaster management sector in Bangladesh has experienced an influx of new concepts and approaches. The GoB has taken a number of significant steps during the last few years for building up institutional arrangements from national to the union levels for effective and systematic disaster management facilitating mitigation to the sufferings of disaster victims in Bangladesh. To maintain proper coordination amongst the concerned ministries, departments, line agencies, local 
government body (LGD) and community people, and also to ensure their proper functioning to mitigate sufferings of the people, the GoB has formulated a set of mechanisms for council and committees from national down to the grass-root levels. For the mechanisms to be best operative, the Standing Orders on Disaster (SOD) act as a guidebook (www.adrc.asia). Major approaches have switched from technology-based hazard control to communitybased disaster risk management, which aims to reduce human vulnerability and build resilient communities (MoFDM 2009). For this purpose, disaster management committees are set up within each union. The committee prepares a disaster action plan and maps, showing hazard risks and available resources in the union. Members of the community take part in this process utilizing PRA methods (DMB 2008). It is the committee's responsibility to disseminate warning signals, carry out evacuation, search and rescue, distribute relief and operate shelter centers, based on the disaster action plan. Community-Based Approach (CBA) which emphasizes the total participation of all people facing any hazard or disaster and makes sure to render all possible services to the community (www.adrc.asia). The existing system for disaster management in the country covers activities at normal times for important disaster management aspects like mitigation/prevention, preparedness, response and recovery (Shafie 2009).

Comprehensive Disaster Management Program has designed to adopt an umbrella program approach that encompasses all aspects of risk management and in so doing facilitates to move from a single agency response and relief strategy to a whole of government holistic strategy that addresses the issue of community vulnerability. It is a strategic institutional and programming framework that is meant to optimize the reduction of long-term risk and the operational capacities for responding to emergencies and disaster situations related to each of the major hazards or potential emergency situations and action to mitigate sufferings and improve recovery from these events. CDMP has the main focus on capacity building of the community, partnership development, community empowerment, research and information management and response management (www.adrc.asia). Gender concerns are clearly addressed within the documentation of this new policy. But, often gender issues vanish from the discussion list at the community level. Even when they are discussed, some key issues are seldom 
mentioned while there are certain sets of women's concerns that are easily recognized and included in the disaster action plan.

\section{Objectives of the Study}

The main objective of the study is to identify the vulnerabilities and coping strategies of women in disaster. In this purpose the specific objectives are:

a) to analyze women's situation in disaster and their needs and problems to survive throughout the disaster;

b) to discover the harmful impacts of disaster over women's physical and mental health;

c) to know their own preparedness techniques and recovery strategies;

d) to identify the drawback programs or activities taken by the government and other organizations for disaster affected women; and

e) to make some suggestions for remedy of the vulnerability and to improve their capacity to cope with disaster.

\section{Definition of the Concepts}

Vulnerability: Vulnerability is the condition determined by physical, social, economic and environmental factors or processes, which increase the susceptibility of a community to the impact of hazards (UN 2009). Vulnerability is 'insecurity, the reverse of security'; it reflects "the characteristics of a person or group in terms of their capacity to anticipate, cope with, resist, and recover from the impact of a natural hazard." It involves a combination of factors that determine the degree to which someone's life and livelihood is put at risk by a discrete and identifiable event in nature or in society (Blaikie et al 1996:8). Vulnerability refers to exposure to contingencies and stress and difficulty in coping with them. It has two components: i) an 'external' side of risks, shocks and stress to which a structure, individual, household, community or nation is subject; and ii) an 'internal' side of lack of resources to cope without damaging loss (Hossain et al 1994). A human condition or process is resulting from physical, social, economic and environmental factors which determine the livelihood and scale of damage from the impact of a given hazard. 
Coping Strategies: In disaster management, coping means the trends and techniques where people gain their expected results by using their property. It is very much related with capacity. Strategies can be defined as a set of activities or mechanism by which people try to survive in disasters, recover their situation and develop their conditions after disaster.

Coastal Area: In this study, coastal area means the places situated beside the Bay of Bengal and many rivers of Bangladesh. The coastal areas of Bangladesh are facing the Bay of Bengal with an area of 47,201 sq. km. covering 19 districts: Bagerhat, Barguna, Barishal, Bhola, Chandpur, Chittagong, Cox's Bazar, Feni, Gopalganj, Jessore, Jhalokati, Khulna, Lakshmipur, Narail, Noakhali, Potuakhali, Pirojpur, Satkhira and Shariatpur (CPD 2000).

\section{Methodology of the Study}

The present study is both qualitative and quantitative in nature. Sample survey has been taken as research method. Purposive and multi-stage sampling techniques have been used for selecting research area and the respondents. The parts of Khulna, Satkhira, Bagerhat, Barguna and Chandpur area have been selected which are badly affected by cyclone SIDR, AILA, riverbank erosion and other natural calamities in 2009. Twenty upazilas of those districts have been affected by disaster 2009 entirely. Two districts namely Satkhira and Bagerhat have been selected purposively. From these two districts, two upazilas named Shamnagar from Satkhira district and Sarankhola from Bagherhat district have been selected through purposive sampling for conducting the study. 120 respondents (15-65 years women) have been selected for data collection by applying random sampling technique that is affected in SIDR or AILA. Each respondent irrespective of color, caste and religion is considered as a unit of analysis.

Data of the study have been collected from both primary and secondary sources. Primary data have been collected from selected samples through interview and observation. Secondary data have been gathered from published and unpublished research reports, journals, books, as well as from record and documents of relevant 
agencies. Primary data have been collected by interview schedule. For this purpose, a structured interview schedule (close and open ended) is prepared for data collection, which have been pre-tested prior to the field work in order to improve its reliability and validity. Requisite data are collected from the selected women by direct/face to face interview. Moreover, observation technique has been applied for data collection. However, it is stated earlier that secondary data have been gathered from various documents.

At first, the collected data have been edited properly. The necessary steps are also taken for creating codes of qualitative data. Then the data are directly manipulated through statistical software, SPSS for windows. All processing and summarizing of numeric data have been followed by descriptive statistics. Both bi-variate and multi-variate analysis have been adopted. In analyzing qualitative data, description and explanation of themes and concepts is presented in a narrative way.

\section{Study Findings and Data Analysis}

\section{Vulnerable Situation of Women During Disasters}

With increasing climate variability, salinity of drinking water sources is becoming a major problem for the people of southwest part of Bangladesh. During the dry season, when lack of portable water becomes an acute crisis for households, it becomes the responsibility of women to provide drinking water for their families. Since water sources are affected by high salinity, women need to travel long distances, sometimes up to 2-3 kilometers on foot every day over rough route, in search of water. It is quite well known that women, children, elderly and person with disability are more vulnerable than the other section. It has been noticed that women, children, elderly, people with disabilities and pregnant women are more vulnerable than the other section. During disaster, they are left behind to leave in cases of emergency because they lack knowledge, mobility and resources.

Gender discrimination is at all levels of the disaster process; risk, preparedness, response, physical and psycho-social impact and recovery. Women are more likely to suffer from malnutrition. Moreover, their ability to cope with injuries, infections and diseases 
are reduced. Institutional health care and sanitation facilities are very poor on coastal areas. The primary health care of families is mostly dependent on the traditional knowledge and local quack doctors. Many women refrain from going to shelters during a disaster or when a warning signal is issued due to loss of privacy and physical and mental abuse and torture. Women often face additional physical insecurity and loss of dignity while collecting relief during or after a disaster. Women's vulnerability is further increased when a male head of the household dies. Due to SIDR and ALILA, women have lost their entire living and working situation, and additionally, their capital equipment.

In addition, women are vulnerable to reproductive and sexual health problems. The study shows the adverse reproductive outcomes such as early pregnancy loss, premature delivery and delivery-related complications. In most cases, they have to walk long distances and standing long queues for collecting relief with their wet clothes clinging to their bodies. Post disaster rehabilitation is often overlooked due to gender discrimination. Weather forecasting information networks or early warning systems often do not take into account women of the coastal areas. Due to their limited access to information, women are less able to minimize risks.

Disaster damages livestock (i.e. cows, goats, and buffaloes), poultry (i.e. chickens, ducks), fisheries, trees, crops (i.e. rice, wheat, nuts, chilies, and lentils), seeds and animal fodder. During and after disasters, the lack of fodder for livestock and poultry results in reduced milk and meat production. Again, due to damages infrastructure and communication systems, women cannot access the market to sell food such as milk, eggs, vegetables or other products. Women are forced to trade with lower prices offered by male buyers within the village. As a result, there is a net loss in income which makes it even harder for households to cope with disasters.

\section{Coping Strategies and Adaptation}

Women in coastal areas try to cope with disasters with their traditional knowledge and arts. This traditional strategy becomes a little help due to change of the nature of disasters. At the time of 
flood or cyclone season, women try to make their houses more resilient to disasters with locally available resources likely strong pole, straw, increasing the height of foundation of the households and the level of cow sheds. This indigenous technique is often used to protect goats and poultry from flood water. During disasters, women look after children, elderly and disabled family members. In flood-prone areas, women prepare elevated platforms for family members with disabilities, using the chouki (traditional bed) with bamboo and wood.

In coastal areas, women control homestead-based livelihoods, livestock, fisheries, trees, seeds and animal fodder. Despite the limited resources in coastal areas women play a significant role in food preservation to combat the adverse situation. Women preserve dry food (such as rice, onion, garlic, puffed rice, gur etc.), fuels, candle, matches, ropes and medicine at home and prepare portable mud stoves for future use. They often collect firewood to store in dry places and store fodder for domestic animals. Women of coastal land are also engaged in drying fish. By drying fish they can earn more money as well as meet the protein deficiency. Women on coastal lands are engaged in the entire process of crop production. They are very skillful in this process by using indigenous knowledge and available resources. In post disaster period, women are also engaged in homestead gardening. They use rooftops and backward spaces to grow various vegetables and fruits.

In coastal areas, rearing and sale of livestock and poultry are important economic activities almost entirely conducted by women. Women's scientific knowledge, innovations and adaptations are demonstrated in their care of livestock. They know what kind of fodder will keep livestock healthy and will produce more milk. In coastal areas, women prefer to rear chickens because they stay around the homestead, unlike ducks, which swim away and get lost. Land mortgaging, selling, or borrowing from neighbors are the common strategies for survival. In many cases, women are compelled to migrate to other places as an adaptation strategy. Female migrants mostly engage in the informal urban labor market. The major activities that employ women in urban areas include serving as domestic helps, brick breaking, hotel workers, day 
laborers and working in the garments industry. Many women are engaged in begging for survival. In coastal areas, women are now part of microfinance organizations, using their memberships to access loans.

\section{Data Analysis}

The age structures of the respondents are 15-20 years (10.33\%), 21-30 years $(24.67 \%), 31-35$ years $(15.67 \%), 35-40$ years $(20.33 \%), 41-45$ years $(10.33 \%), 46-50$ years $(8.33 \%)$ and 50 years or above $(10.33 \%)$ respectively. Most of the respondents are Muslim (83.33\%) and Hindu (16.67\%). The larger portion of the respondents are married $(63.33 \%), 21.67 \%$ are unmarried, $8.33 \%$ are widower and $6.67 \%$ are divorced respectively. Divorced rate is high in the coastal areas than the national rate. One of the main causes is poverty. Besides, generally women are less interested in coastal areas to take the legal aid due to lack of administrative facilities. The educational status of the respondents in coastal areas is very poor. Most of them are illiterate (69.30\%). Only $31.70 \%$ respondents are literate. The number of family members of most respondents is up to eight (43.33\%). 20 respondents have family members up to six $(33.33 \%)$. $16.67 \%$ respondents have eight or above family members. Only $6.67 \%$ has up to four family members. The growth rate is high in coastal areas. On an average, there are seven members in every family.

The government, NGOs and many other philanthropists and associations provide relief during and after disaster. 20 percent respondents report that they do not get relief, food, medicine or other things. It is noticed that most of the disaster affected women get raw food that needs to be processed or cooked. But it is sometimes very difficult to cook food as there is scarcity of fuel, hearth, water and other necessary things. About 70 percent informs that their living places are wet and dirty. It can be said that the shelter places are not provided with good environment and for this women and children have a great risk to be affected by different diseases. Some of the families and the members migrate to different places. This study shows that 12 percent migrate from coastal areas to urban areas or other places which increases the vulnerability of 
women and children. This kind of migration is very much common in our country and it is increasing at a high rate.

Table 1: Information about disaster faced by the respondents

\begin{tabular}{|l|c|c|}
\hline Types of disaster & $\begin{array}{c}\text { Frequency } \\
(\mathbf{N = 1 2 0})\end{array}$ & Percentage \\
\hline Cyclone & 60 & 50 \\
\hline Tidal surge & 110 & 91.67 \\
\hline Flood & 80 & 66.67 \\
\hline River erosion & 30 & 25 \\
\hline Excessive rainfall & 20 & 16.67 \\
\hline Tsunami & 4 & 3.33 \\
\hline
\end{tabular}

Source: Field work [More than one answer is possible]

The above table indicates that most of the respondents have faced tidal surge, flood and cyclone $(91.67 \%, 66.67 \%$ and 50\%) respectively. River erosion, tsunami and excessive rainfall are the other disasters faced by the respondents. Natural disaster is the constant company of coastal population. They are faced more than one disaster every year.

Table 2: Information about getting warning signal of disaster

\begin{tabular}{|c|c|c|}
\hline Getting signal & Frequency & Percentage \\
\hline Yes & 16 & 13.3 \\
\hline No & 104 & 86.7 \\
\hline Total & 120 & 100 \\
\hline
\end{tabular}

Source: Field work

The above table shows that 104 respondents $(86.67 \%)$ do not get any signal of disaster. Only 13.33 percent respondents get signal of disaster. It means that most of the women do not get warning signal of disasters due to lack of modern weather 
forecasting technology likely radio, T.V and so on. Most of the inhabitants of coastal areas depend on the indigenous technology for getting the signal of disaster. Cloud cover, wind direction and speed, fog, water color and temperature, rising water level bear the signs of flood, rainfall and drought. Movement and behavior of insects and animals bear the signal of the disaster, as ants with eggs in the mouth start climbing up for shelter before flood; grasshoppers fly unitedly before heavy rain and storm; if dog cries in pathetic voice flood will come and/or food crisis will prevail; if fox calls in day time, crow calls at night flood or a storm will soon take place. Still today, the coastal people, excluded from modern information system, do apply indigenous techniques to face any disaster, keep their eyes active on how monsoon winds and change of seasons for forecasting disasters. 
Table 3: Information about shelter place of the respondents

\begin{tabular}{|l|c|c|}
\hline Shelter place & Frequency & Percentage \\
\hline Cyclone Center & 14 & 11.67 \\
\hline School & 10 & 8.33 \\
\hline Bridge & 16 & 13.33 \\
\hline Road & 66 & 55 \\
\hline Relative's residence & 10 & 8.33 \\
\hline Own residence & 4 & 3.33 \\
\hline Total & 120 & 100.0 \\
\hline
\end{tabular}

Source: Field work

This table shows that most of the respondents (55\%) take shelter on the roads. $11.67 \%$ take shelter in the cyclone centre and $13.33 \%$ take shelter on the bridge. The percentage of the respondents who take shelter in schools and relatives residences is 16.66. Only $3.33 \%$ respondents stay in their own residence during the disaster.

Table 4: Information about the facilities getting by the respondents in the shelter centre

\begin{tabular}{|l|c|c|}
\hline Facilities & Frequency & Percentage \\
\hline Sufficient space & 4 & 3.33 \\
\hline Sufficient food & 10 & 8.33 \\
\hline Sufficient light & 20 & 16.67 \\
\hline Separate place for male and female & 14 & 11.67 \\
\hline Lack of facilities & 72 & 60 \\
\hline Total & 120 & 100 \\
\hline
\end{tabular}

Source: Field work 
The study shows that most of the respondents $(60 \%)$ face lack of facilities in the shelter centres. 11.67 percent respondents opine that there are separate places for male and female at the shelter centres. Owing to the lack of separate places women can not keep their privacy. About three-fourth respondents report that they do not get sufficient food during and after disaster. There is no sufficient water, medicine, clothes, light, cooking arrangement and logistic supply in the shelter centres. Only a small number of respondents $(28.33 \%)$ opine that there is sufficient space, food and light at shelter centres.

Table 5: Information about facing unexpected events during disaster

\begin{tabular}{|l|c|c|}
\hline Events & $\begin{array}{c}\text { Frequency } \\
(\mathbf{N = 1 2 0})\end{array}$ & Percentage \\
\hline Theft & 20 & 16.67 \\
\hline Robbery & 22 & 18.33 \\
\hline Sexual harassment & 25 & 20.83 \\
\hline Physical and mental torture & 60 & 50 \\
\hline No event & 14 & 11.67 \\
\hline
\end{tabular}

Source: Field work [More than one answer is possible]

From the above table, it is observed that most of the female respondents face various kinds of unexpected events at the time of disaster. 50 percent respondents face physical and mental torture. The study shows that a good number of women $(20.83 \%)$ face sexual harassment. They face also theft (16.67\%) and robbery (18.33\%) respectively. Only 11.67 percent do not face any unexpected situation at the time of disaster. All these factors create psycho-social impact on women's life. Disaster has its devastating impact on all areas of life-physical, psychological, social and emotional and all these reactions are interlinked. In any disaster the magnitude of mental health problems is enormous. 
Table 6: Information about the necessary food stored and types of food

\begin{tabular}{|c|c|c|c|c|c|}
\hline $\begin{array}{c}\text { Food stored } \\
\text { and types } \\
\text { of food }\end{array}$ & Frequency & Percentage & $\begin{array}{l}\text { Types of } \\
\text { food }\end{array}$ & Frequency & Percentage \\
\hline Yes & 34 & 28.33 & Dry food & 12 & 10 \\
\hline No & 86 & 71.67 & $\begin{array}{l}\text { Food need } \\
\text { to process }\end{array}$ & 20 & 16.67 \\
\hline \multirow{2}{*}{ Total } & \multirow{2}{*}{120} & \multirow{2}{*}{100} & Other & 2 & \multirow{2}{*}{1.67} \\
\hline & & & Total & 34 & \\
\hline
\end{tabular}

Source: Field work

This study shows that most of the respondents' families (71.67\%) can not store food for combating the disaster due to their poverty. Only 28.33 percent can store different kinds of food before disaster. In most cases, many of them fail to bring these at shelter places. 10 percent respondents can store dry food like chira, muri, gur and so on. 16.67 percent respondents notice that stored food needs to be cooked which is not possible owing to the lack of the fuel or cooking facilities.

Table 7: Information about capacity for buying food and medicine during disaster

\begin{tabular}{|l|c|c|}
\hline \multicolumn{1}{|c|}{ Capacity } & Frequency & Percentage \\
\hline Sufficient capacity & 14 & 11.67 \\
\hline Insufficient capacity & 40 & 33.33 \\
\hline No capacity & 66 & 55 \\
\hline Total & 120 & 100 \\
\hline
\end{tabular}

Source: Field work 
This table shows that most of the respondents (55\%) have no capacity for buying food and medicine. 33.33 percent has insufficient capacity and only 11.67 percent has the capacity to buy food and medicine during and after disaster. They become vulnerable due to loss their food, assets, livestock, agricultural production and loss of job.

Table 8: Information about the availability of drinking water during and after disaster

\begin{tabular}{|l|c|c|}
\hline \multicolumn{1}{|c|}{ Drinking water } & Frequency & Percentage \\
\hline Available & 18 & 15 \\
\hline Little amount & 22 & 18.33 \\
\hline Not available & 80 & 66.67 \\
\hline Total & 120 & 100 \\
\hline
\end{tabular}

Source: Field work

The table shows that drinking water is available for only 15 percent respondents. 66.67 percent respondents notice that pure drinking water is not available at disaster period. There is a significant correlation between the availability of pure drinking water and the types of diseases suffered by the respondents during and after disaster. This study explores that almost all the respondents are attacked by various diseases during and after disaster. Lack of medical facilities, malnutrition, lack of uncontaminated drinking water and lack of proper sanitation facilities are the common scenario during disaster. 
Table 9: Types of diseases suffered by the respondents

\begin{tabular}{|l|c|c|}
\hline \multicolumn{1}{|c|}{ Types of diseases } & $\begin{array}{c}\text { Frequency } \\
\text { (N=120) }\end{array}$ & Percentage \\
\hline Diarrhea & 60 & 50 \\
\hline Snake bites & 4 & 3.33 \\
\hline Cholera & 22 & 18.33 \\
\hline Fever & 46 & 38.33 \\
\hline Fracture & 8 & 6.67 \\
\hline Skin diseases & 40 & 33.33 \\
\hline No Traumatic situation & 20 & 16.67 \\
\hline
\end{tabular}

Source: Field work [More than one answer is possible.]

The study shows that 83.33 percent of the respondents suffer from traumatic situation during and after disaster and 16.67 percent does not suffer from any traumatic situation. From the table it is noticed that 50 percent of the respondents suffer from diarrhoea, 3.33 percent from snake bite, 18.33 percent from cholera, 38.33 percent from fever, 6.67 percent from fracture and 33.33 percent from skin diseases. Most of the respondents suffer from water borne diseases during and after disaster.

Table 10: Information about first aid and medical treatment getting by the respondent

\begin{tabular}{|l|c|c|}
\hline \multicolumn{1}{|c|}{$\begin{array}{c}\text { Sources of getting } \\
\text { treatment }\end{array}$} & Frequency & Percentage \\
\hline Local rural doctor & 50 & 41.67 \\
\hline MBBS doctor & 40 & 33.33 \\
\hline Kabiraj & 10 & 8.33 \\
\hline Jhar-fuk & 20 & 16.67 \\
\hline Total & 120 & 100 \\
\hline
\end{tabular}

Source: Field work 
This table notices that only 33.33 percent respondents take the treatment by MBBS doctors during or after disaster. 25 percent of them do not get any medical support without kabiraj and jharfuk. About 41.67 percent of the respondents get medical treatment from the local quack doctors. Though a good number of respondents get treatment from MBBS doctors, they are not available at right time in coastal areas. Specialized doctors stay at the upazila sadar or district headquarters which becomes impossible many times for women going to the headquarters due to the lack of transportations. It is noted that a good number of coastal population depends on rural quack physicians for their treatment. Kabiraj and jhar-fuk still exist in coastal areas.

Table 11: Information about use of healthy sanitary latrine of the respondents

\begin{tabular}{|c|c|c|}
\hline Use of healthy sanitary latrine & Frequency & Percentage \\
\hline Yes & 4 & 3.33 \\
\hline No & 116 & 96.67 \\
\hline Total & 120 & 100 \\
\hline
\end{tabular}

Source: Field work

Use of healthy sanitary latrine is an important indicator for maintaining good health. The above data indicate that only 3.33 percent respondents have the opportunity to use healthy sanitary latrine. More than 96 percent respondents do not get any opportunity to use healthy sanitary latrine. There is no separate latrine facility for women at shelter places. It indicates the vulnerable situation of women. Women and adolescent girls suffer most as sanitation systems are destroyed. Many women report that they refrain from using the toilet during the day and consequently suffer from urinary tract infections. Pregnant women, lactating mothers and differently disabled women suffered the most, as they found it difficult for moving during and after disaster. Sometimes women can not express their problems. 
Table 12: Information about the working situation of the respondents before and after disaster

\begin{tabular}{|c|c|c|c|c|c|c|c|c|}
\hline $\begin{array}{c}\text { Before } \\
\text { disaster } \\
\text { (Work) }\end{array}$ & Frequency & Percentage & $\begin{array}{c}\text { Types } \\
\text { of } \\
\text { work }\end{array}$ & Frequency & Percentage & $\begin{array}{c}\text { After } \\
\text { disaster } \\
\text { (Work) }\end{array}$ & Frequency & Percentage \\
\hline $\begin{array}{l}\text { Househol } \\
\mathrm{d} \quad \text { and } \\
\text { various } \\
\text { types } \\
\text { of works }\end{array}$ & 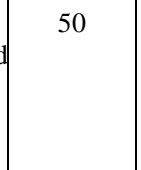 & 41.67 & $\begin{array}{l}\text { Day } \\
\text { labor }\end{array}$ & 20 & 16.67 & $\begin{array}{c}\text { Household } \\
\text { and } \\
\text { various } \\
\text { types of } \\
\text { works }\end{array}$ & 10 & 8.33 \\
\hline $\begin{array}{l}\text { Househol } \\
\mathrm{d} \text { works }\end{array}$ & 70 & 58.33 & $\begin{array}{c}\text { Maid } \\
\text { servant }\end{array}$ & 6 & 5 & $\begin{array}{c}\text { Household } \\
\text { works }\end{array}$ & 70 & 58.33 \\
\hline \multirow[t]{3}{*}{ Total } & \multirow[t]{3}{*}{120} & \multirow[t]{3}{*}{100} & $\begin{array}{c}\text { Agricul } \\
\text { tural } \\
\text { work }\end{array}$ & 14 & 11.67 & $\begin{array}{l}\text { Loss } \\
\text { of } \\
\text { work }\end{array}$ & 40 & 33.33 \\
\hline & & & Other & 10 & \multirow[t]{2}{*}{8.33} & \multirow[t]{2}{*}{ Total } & \multirow[t]{2}{*}{120} & \multirow[t]{2}{*}{100} \\
\hline & & & Total & 50 & & & & \\
\hline
\end{tabular}

Source: Field work

The above data show that 41.67 percent respondents are engaged in various types of work (day labor $16.67 \%$, maid servant $6 \%$, agricultural work $11.67 \%$ and other $10 \%$ ) including household activities. 58.33 percent respondents are only engaged of their household activities before disaster. After disaster 33.33 percent respondents lose their jobs who are engaged in day labor, maid servant, agricultural and other activities. Besides, they report that they lose their household activities after disaster. This study shows that 33.33 percent disaster affected women cannot join their working place after disaster and therefore cannot earn which create the situation more vulnerable for them and their family.

\section{Recommendations}

Women of coastal areas of Bangladesh are the worst sufferers in disasters. Government and some NGOs/INGOs are trying to reduce the vulnerability of people of coastal areas. It is noticed that proper policy, planning and good governance can also reduce any sort of hazard and can increase the socio-economic situation through different micro credit schemes in collaboration of 
government, non-government and international agencies. In this regard, following recommendations can be made for mitigating and reducing sufferings of the coastal people:

1. Women should be given priorities in all policies, planning and programs related to disaster management.

2. It is essential to modernize the meteorological and hydrological networks for forecasting and warning systems. Emergency response systems and supporting livelihood strategies should be taken based on local realities, especially for women and children.

3. Construction of shelters should be well constructed with multipurpose use and there should be separated facilities for women. Shelters should be constructed at a place where access of women will be direct and easy during the disaster. Transport networks should be developed to expedite movement and rescue people and other things during disaster.

4. Facilities should be made to preserve sufficient amount of drinking water during and after disaster.

5. Community-based awareness raising programs should be strengthened. Seminar, symposium and workshop will have to be arranged in coastal areas and ensure the participation of women in these programs. Disaster mitigation strategies and disaster preparedness techniques should be included in school, college and university level curriculum. Besides, short course, diploma and training programs have to be introduced both in urban and rural areas.

6. GO and NGOs should take infrastructure development and income generating activities for women in the coastal belts. We must recognize that poor women are affected worst by disasters and it must be ensured their that needs are prioritized. It should be ensured that women have equal access to developmental activities. 
7. Local administration should take strong initiatives to avoid the events of theft, robbery, and hijacking, torturing women and other unexpected events during disasters.

8. It must be ensured that women have access to education and training programs so that they can implement adaptation and coping strategies.

9. More and more research should be conducted to find out the coping and mitigation strategy, appropriate housing structures and other relevant issues for coastal areas of Bangladesh.

In fine, we conclude that Bangladesh is the worst victim of climate change and global warming in the world. The climate is becoming more variable and creating additional risks. Women are becoming more vulnerable in this changing situation. Actually the social, economic, cultural and political contexts of Bangladesh's women make them overall more vulnerable to climate change and global warming. In this study, the researcher has tried to find out the range of women's vulnerability in coastal areas during and after disasters and tried to know their coping strategies. From these findings, it can be easily said that though their coping strategies have been recognized worldwide, these are inadequate for balanced and sustainable development. In the context of the above stated issues, it can be said that the authority and the implementing agency must ensure women's participation in every planning and developmental programs.

\section{References}

Action Aid USA. 2009. Compensating for Climate Change: Principles and Lessons for Equitable Adaptation Funding, Dhaka.

Alam, K. 2005. Risks, Lives and Livelihoods of Coastal Community, Nirapad Newsletter, $9^{\text {th }}$ Issue, Dhaka.

Ali, A. 1999. Climate Change Impacts and Adaptation Assessment in Bangladesh, Climate Research, Vol. 12, Space Research and Remote Sensing Organization (SPARRSO), Dhaka. 
Bangladesh Bureau of Statistics (BBS). 2006. Ministry of Planning, The Government of the People's Republic of Bangladesh.

Blaikie, P. T. Cannon, I. Davis, and B. Wisner. 1994. At Risk: Natural Hazards, People's Vulnerability and Disasters. Routledge, London.

Centre for Policy Dialogue (CPD). 2000. Female Headed Households in Rural Bangladesh: Strategies for Wellbeing and Survival, CPD, World Bank and UNFPA.

Disaster Management Bureau. 2008. National Disaster Management Policy, Ministry of Food and Disaster Management, The Government of the People's Republic of Bangladesh.

Disaster Management in Bangladesh at www.adric.asia accessed on 1 June 2011

Hossain, H, Cole P. Dodge, and F.H. Abed (ed.) 1996. From Crisis to Development: Coping with Disasters in Bangladesh. Dhaka, University Press Ltd.

Ministry of Food and Disaster Management. 2009. Journal of Disaster Management, The Government of the People's Republic of Bangladesh.

Newmayer, M. and Plumper, S. 2007. Coping and Adaptation Strategies of Household: A Case of Bangladesh, New Delhi, India.

Nizamuddin, K. (ed.) 2001; Disaster in Bangladesh: Selected Readings, Disaster Research Training and Management Center, Department of Geography and Environment, University of Dhaka.

Roy, K. K., U. Mehedi, H., Sultana, T. and Ershad, D. M. 2009. Initial Damage Assessment Report of Cyclone AILA with Focus on Khulna District, Unnayan Onneshan, Humanity Watch, Nijera Kori, Bangladesh.

Soussan, J. and Anjan D. 2002. Coastal Development and Livelihoods in Bangladesh, Department for International Development (UK), Dhaka.

Shafie, H. et. al. 2009. Endowed Wisdom: Knowledge of Nature and Coping with Disaster in Bangladesh, Comprehensive Disaster Management Program, Dhaka. 
Tom, M. 2007. We Know what We Need: South Asian Women Speak out on Climate Change Adaptation, Institute of Development Studies (IDS), The University of Sussex, UK.

World Bank. 2005. Natural Disaster Hotspots: A Global Risk Analysis, Disaster Risk Management Series, No. 5, Dhaka, World Bank Office. 